\title{
PENGARUH MODEL PEMBELAJARAN TREFFINGER TERHADAP KEMAMPUAN KOMUNIKASI MATEMATIS SISWA KELAS X MIA SMA NEGERI 1 SUKASADA
}

\author{
Q. 'Aini, I. G. N. Yudi Hartawan, I. W. Puja Astawa \\ Program Studi Pendidikan Matematika \\ UniversitasPendidikan Ganesha \\ Singaraja, Indonesia \\ e-mail:aqurrotul8@gmail.com,hartawan.math@gmail.com puja.astawa@undiksha.ac.id
}

\begin{abstract}
Abstrak
Penelitian ini bertujuan untuk mengetahui pengaruh model pembelajaran Treffinger terhadap kemampuan komunikasi matematis siswa. Jenis penelitian yang digunakan dalam penelitian ini adalah eksperimen semu (quasi experiment) dengan pendekatan kuantitatif deskriptif. Desain penelitian yang digunakan adalah post-test only control group design. Populasi penelitan ini adalah seluruh X MIA SMA Negeri 1 Sukasada tahun ajaran 2018/2019 yang berjumlah 47 siswa dan tersebar ke dalam 2 kelas. Data kemampuan komunikasi matematis siswa diperoleh melalui tes uraian. Analisis data menggunakan statistik deskriptif yaitu dengan menghitung nilai rata-rata, varians, standar deviasi, dan konversi nilai. Berdasarkan hasil dengan pertitungan statistik deskriptif diperoleh nilai rata-rata kelas eksperimen sebesar 70,125 dan nilai rata-rata kelas kontrol sebesar 62,59 sehingga $\bar{x}_{e}>\bar{x}_{k}$, serta standar nilai dapat dikatakan bahwa kemampuan komunikasi matematis siswa yang mengikuti pembelajaran dengan model pembelajaran Treffinger lebih baik dari kemampuan komunikasi matematis siswa yang mengikuti pembelajaran dengan model pembelajaran konvensional. Jadi dapat disimpulkan bahwa model pembelajaran Treffinger berpengaruh positif terhadap kemampuan komunikasi matematis siswa.
\end{abstract}

Kata kunci : model pembelajaran Treffinger, pembelajaran konvensional, kemampuan komunikasi matematis.

\begin{abstract}
This study aims to determine the effect of the Treffinger learning model on students' mathematical communication skills. The type of research used in this study is quasi experiment with descriptive quantitative approach. The research design used is post-test only control group design. The population of this research is all X MIA SMA Negeri 1 Sukasada in 2018/2019 school year which total 47 students and spread into 2 classes. Data on students' mathematical communication skills is obtained through a description test. Data analysis using descriptive statistics is to calculate the average value, variance, standard deviation, and value conversion. Based on the results with descriptive statistical calculations obtained the average value of the experimental class is 70.125 and the average value of the control class is 62.59 so that $\bar{x}_{e}>\bar{x}_{k}$, it can be said that the mathematical communication skills of students who take learning with Treffinger learning models are better than Mathematical communication skills of students who follow learning with conventional learning models. So it can be concluded that Treffinger's learning model has a positive effect on students' mathematical communication skills.
\end{abstract}

Keywords : Treffinger learning models, conventional learning, mathematical communication skills.

\section{PENDAHULUAN}

Pembelajaran

matematika

merupakan pembelajaran yang diwajibkan pada setiap jenjang pendidikan. Matematika itu sendiri merupakan suatu bahasa yang dalam bentuknya berupa 
lambang-lambang yang didefinisikan dengan cermat, jelas, akurat, serta representasinya dengan simbol dan istilah matematika (Suriasumantri, 2003).

Menurut NCTM (2003) dalam Principles and Standards for School Mathematics merumuskan standar kemampuan dasar matematika secara umum yaitu kemampuan pemecahan masalah, penalaran, komunikasi, koneksi, dan representasi. Sejalan dengan tujuan tersebut, Permendikbud no. 22 tahun 2016 tentang standar isi pendidikan dasar dan menengah menetapkan bahwa kompetensi yang harus dimiliki siswa meliputi ranah sikap, pengetahuan, dan keterampilan. Pada ranah pengetahuan dan ranah keterampilan tersebut secara umum siswa dituntut agar bisa mengamati, menanya, mengumpulkan informasi, mengasosiasi, dan mengkomunikasikan matematika tersebut (Permendikbud, 2016). Dengan demikian, komunikasi matematis merupakan salah satu kemampuan yang harus dikuasai oleh siswa. Dalam kehidupan sehari-hari pastinya tidak terlepas dari komunikasi, khususnya dalam pembelajaran matematika.

Ansari (2012) juga menyatakan bahwa komunikasi matematik terdiri dari komunikasi lisan dan komunikasi tulisan. Komunikasi lisan tersebut dapat diartikan sebagai suatu peristiwa untuk saling berinteraksi yang terjadi dalam pembelajaran secara kelompok kelas maupun kelompok kecil. Selain itu, komunikasi lisan ini merupakan suatu peralihan pesan materi matematik yang dipelajari, baik antar guru dan siswa maupun antar siswa itu sendiri. Sedangkan komunikasi tulisan merupakan keterampilan siswa dalam menggunakan simbol, notasi, dan struktur matematik baik dalam bentuk penalaran, koneksi, maupun dalam pemecahan masalah.

Menurut Umar (2012) menyatakan ada dua alasan mengapa pembelajaran matematika terfokus pada pengkomunikasian. Pertama, matematika pada dasarnya adalah suatu bahasa. Kedua, matematika dan belajar matematis dalam bathinnya merupakan aktivitas sosial. NCTM (2003) menyatakan bahwa siswa dapat mengkomunikasikan ide-ide matematika mereka secara lisan dan tertulis kepada rekan-rekannya dan guru mereka.

Dari pendapat-pendapat tersebut maka dapat disimpulkan komunikasi matematis merupakan kemampuan menggunakan bahasa matematika untuk mengekspresikan ide-ide matematis dan menyampaikan pendapat dengan tepat, singkat dan logis. Dengan adanya komunikasi tersebut, maka siswa bisa saling bertukar pendapat dengan temanteman maupun gurunya. Selain itu, guru juga bisa memahami kemampuan siswa tersebut dalam mengiterpretasikan dan menyampaikan pemahamannya, sehingga siswa mampu berbagi ide dan memperjelas pemahaman, serta ide-ide tersebut dapat direfleksi, diperbaiki, didiskusikan, dan dikembangkan.

Indikator kemampuan komunikasi matematis yang digunakan dalam penelitian ini berdasarkan teori NCTM (2003) adalah: a) Mengekspresikan ide-ide matematis melalui tulisan dan menggambarkannya dalam bentuk gambar, tabel, grafik, atau model metematika yang lain; b) Memahami, menginterpretasi, dan mengevaluasi ideide matematika baik secara tulisan maupun visual lainnya; dan c) Menggunakan istilahistilah, notasi-notasi matematika dan struktur-strukturnya untuk menyajikan ideide matematika secara tertulis maupun visual lainnya.

Dengan demikian, kemampuan komunikasi matematis siswa sangat penting untuk ditingkatkan. Beberapa hal yang menjadikan pentingnya komunikasi matematis bagi siswa tersebut karena beberapa hal yaitu komunikasi matematika merupakan muara bagi siswa dalam menentukan konsep dan cara penyelesaian matematika. Kemampuan komunikasi matematis juga merupakan modal keberhasilan siswa dalam menentukan solusi masalah dalam mengeksplorasi permasalahan matematika, serta wadah bagi siswa untuk berkomunikasi dengan temannya, yaitu menyampaikan ide-ide guna mengevaluasi dan memberikan alasan yang kuat dari solusi yang didapatkan (Umar, 2012). 
Kenyataannya, dari hasil PISA 2015 menunjukkan rata-rata skor internasional matematika siswa di Indonesia adalah 386, sementara standar rata-rata skor internasional matematika adalah 490. Dengan hasil tersebut, menunjukkan bahwa level kemampuan matematika siswa berada pada tingkatan dapat mengerjakan algoritma dasar, menggunakan rumus, melaksanakan prosedur atau konvensi sederhana. Sedangkan, untuk kemampuan melakukan penafsiran, melakukan refleksi, dan mengkomunikasikan apa yang dikerjakan masih sangat rendah, yaitu dengan hasil skor hampir mendekati nol (OECD, 2016:195). Dari hal tersebut, maka dapat diketahui bahwa kemampuan komunikasi matematis siswa masih tergolong rendah.

Hal yang menyebabkan rendahnya kemampuan komunikasi matematis siswa berhubungan dengan pembelajaran yang dilakukan oleh guru. Guru yang hanya terfokus pada pengajaran materi, dan mencontohkan penyelesaian soal matematika, akan mengakibatkan siswa cenderung belajar dengan mendengarkan \& menonton guru saja. Dengan demikian, siswa tidak dapat menyampaikan ideidenya dan berdiskusi dengan siswa lain. Selain itu, siswa kurang mampu memaparkan penjelasan atau langkahlangkah penyelesaiannya, sehingga kemampuan komunikasi matematis siswa kurang berkembang (Hodiyanto, 2017). Sejalan dengan Undang-undang Nomor 23 tahun 2003, salah satu hal yang perlu diperhatikan dalam proses pendidikan, khususnya pembelajaran matematika yaitu berorientasi kepada siswa (student active learning) (Sanjaya, 2009). Oleh karena itu, diperlukan pemilihan model pembelajaran yang dapat memberikan kesempatan siswa untuk berperan aktif dalam pembelajaran dan dapat mengembangkan kemampuan komunikasi matematis siswa dengan menciptakan suasana belajar yang dinamis, harmonis, dan menarik. Model pembelajaran tersebut adalah model pembelajaran Treffinger.

Model pembelajaran Treffinger merupakan model pembelajaran yang mendorong siswa untuk belajar kreatif, dengan mengintegrasikan dua ranah kognitif dan afektif. Hal tersebut bertujuan agar siswa mampu menyelesaikan masalahnya sendiri sesuai yang di kehendakinya. Guru bertugas sebagai pembimbing agar siswa tidak keluar dari permasalahan (Huda, 2013). Model ini mengajak siswa agar lebih partisipatif dan diharapkan siswa mampu mengutarakan ide-ide dalam penyelesaian masalah dan cara belajar yang bermakna. Model ini memiliki 3 komponen, yaitu Understanding Challange (memahami tantangan) yang terdiri dari dua tahap yaitu tahap menentukan tujuan dan tahap menggali data, Generating Ideas (membangkitkan gagasan), serta Preparing for Action (mempersiapkan tindakan) yang terdiri tahap mengembangkan solusi dan tahap membangun penerimaan.

Penelitian yang menunjukkan bahwa model pembelajaran Treffinger berpengaruh positif terhadap pembelajaran matematika siswa yakni seperti halnya penelitian yang dilakukan oleh Permatasari, dkk (2014), dimana hasil penelitian tersebut menyatakan bahwa kemampuan siswa dalam memecahkan masalah yang mendapatkan pembelajaran dengan model treffinger mengalami peningkatan yang lebih baik dibandingkan dengan siswa yang mendapatkan pembelajaran dengan model konvensional. Kemampuan pemecahan masalah siswa yang baik menunjukkan bahwa siswa dapat memahami masalah dengan baik pula. Dengan demikian siswa bisa menyampaikan idenya dan aktivitas belajar siswa menjadi lebih aktif, sehingga kemampuan pemecahan masalah yang baik dan aktivitas siswa yang meningkat, diharapkan model pembelajaran Treffinger ini juga dapat meningkatkan kemampuan komunikasi matematis siswa.

Selain itu, Wahyuni, dkk (2014) juga menyatakan hal yang sama, dimana hasil penelitiannya menunjukkan bahwa model pembelajaran Treffinger memiliki pengaruh terhadap aktifitas siswa yang semakin meningkat terhadap kemampuan berfikir aljabar dan kemandirian belajar siswa. Hal ini menunjukkan bahwa siswa yang dibelajarkan dengan model treffinger memiliki kemampuan lebih baik daripada siswa yang dibelajarkan dengan model 
konvensional. Oleh karena aktivitas siswa yang meningkat, maka diharapkan kemampuan komunikasi matematis siswa yang dibelajarkan dengan model pembelajaran Treffinger juga akan meningkat dibandingkan dengan siswa yang mengikuti pembelajaran model konvensional.

Berdasarkan pemaparan tersebut, maka penelitian ini bertujuan untuk mengetahui apakah kemampuan komunikasi matematis siswa kelas X MIA SMA Negeri 1 Sukasada yang mengikuti pembelajaran dengan model pembelajaran Treffinger lebih baik daripada kemampuan komunikasi matematis siswa yang mengikuti pembelajaran konvensional.

\section{METODE}

Penelitian ini merupakan penelitian eksperimen semu (quasi experimen). Penelitian eksperimen semu digunakan untuk melihat pengaruh yang ditimbulkan dari perlakuan berbeda yang diberikan kepada masing-masing kelompok, dimana peneliti tidak dapat mengontrol semua variabel dan kondisi eksperimen secara ketat (Sugiyono, 2012). Pendekatan yang digunakan pada penelitian ini yaitu pendekatan kuantitatif dengan metode deskriptif. Populasi dalam penelitian ini adalah seluruh siswa kelas X MIA SMA Negeri 1 Sukasada tahun ajaran 2018/2019. dengan jumlah 47 orang yang tersebar ke dalam 2 kelas, yaitu kelas $X$ MIA 1, dan X MIA 2.

Hasilnya adalah terpilih kelas X MIA 2 sebagai kelas kontrol dan $X$ MIA 1 sebagai kelas eksperimen. Pada kelas kontrol diterapkan pembelajaran konvensional sedangkan pada kelas eksperimen diterapkan model pembelajaran Treffinger. Rancangan penelitian yang dilakukan adalah Post Test Only Control Design. Adapun rancangan penelitian ini disajikan pada Tabel 1.

Tabel 1 Rancangan Penelitian

\begin{tabular}{|l|l|l|}
\hline KELOMPOK & PERLAKUAN & HASIL \\
\hline
\end{tabular}

\begin{tabular}{|c|c|c|}
\hline Eksperimen & $X$ & $Y_{1}$ \\
\hline Kontrol & - & $Y_{2}$ \\
\hline
\end{tabular}

Keterangan:

$X=$ Perlakuan berupa penerapan model pembelajaran Treffinger.

$Y_{1}=$ Hasil kemampuan komunikasi matematis siswa kelas eksperimen.

$Y_{2}=$ Hasil kemampuan komunikasi matematis siswa kelas kontrol.

Adapun instrumen yang digunakan yaitu tes essay (uraian) kemampuan komunikasi matematis. Sebelum dilakukan post test, soal tes kemampuan komunikasi matematis diujicobakan di SMA Negeri 3 Singaraja sebanyak 5 butir soal kemudian diuji validitas konstruk butir dengan menggunakan rumus korelasi product moment $\left(r_{x y}\right)$ diperoleh semua soal valid yakni sebanyak 5 butir soal yang diujicobakan, selanjutnya dilakukan uji reabilitas tes menggunakan rumus Alpha Cronbach diperoleh 0,416 yang termasuk dalam kategori tes pemecahan masalah termasuk dalam kategori reliabilitas rendah sehingga soal-soal tersebut layak untuk digunakan.

Teknik analisis data yang digunakan yakni analisis data statistik deskriptif. Analisis statistik deskriptif digunakan untuk mengetahui gambaran secara umum. Statistik deskriptif adalah statistik yang digunakan untuk menganalisis data dengan cara mendeskripsikan atau mengambarkan data yang telah terkumpul sebagaimana adanya tanpa bermaksud membuat kesimpulan yang berlaku untuk umum atau generalisasi (Sugiyono, 2012).

Hipotesis yang diajukan pada penelitian ini yaitu kemampuan komunikasi matematis siswa kelas X MIA SMA Negeri 1 Sukasada yang mengikuti pembelajaran dengan model pembelajaran Treffinger lebih baik daripada kemampuan komunikasi matematis siswa yang mengikuti pembelajaran konvensional.

\section{HASIL DAN PEMBAHASAN}
A. Hasil Penelitian 
Dari data yang telah terkumpul diperoleh bahwa rata-rata nilai kemampuan komunikasi matematis siswa pada kelompok eksperimen adalah 70,125 dan rata-rata nilai kemampuan komunikasi matematis siswa pada kelompok kontrol adalah 62,59. Rangkuman hasil analisis data nilai kemampuan komunikasi matematis siswa pada kelompok eksperimen dan kelompok kontrol ditujukkan pada Tabel 2 berikut.

Tabel 2 Rangkuman Hasil Analisis Data Kemampuan Komunikasi Matematis Siswa.

\begin{tabular}{|l|c|c|c|}
\hline \multirow{2}{*}{ Statistika } & \multicolumn{2}{|c|}{ Kelas } & Selisih \\
\cline { 2 - 4 } & Eksperimen & Kontrol & 1 \\
\hline $\begin{array}{l}\text { Jumlah } \\
\text { Siswa }(n)\end{array}$ & 24 & 23 & 1 \\
\hline $\begin{array}{l}\text { Maksimum } \\
\left(X_{\text {max }}\right)\end{array}$ & 80 & 79 & 22 \\
\hline $\begin{array}{l}\text { Minimun } \\
\left(X_{\text {min }}\right)\end{array}$ & 55 & 199,08 & 140,787 \\
\hline Rata-rata & 70,125 & 62,59 & 7,535 \\
\hline $\begin{array}{l}\text { Varians } \\
\left(S^{2}\right)\end{array}$ & 58,293 & 14,11 & 6,475 \\
\hline $\begin{array}{l}\text { Simpangan } \\
\text { Baku }(S)\end{array}$ & 7,635 & 193 \\
\hline
\end{tabular}

Dari Tabel 2 dapat terlihat dengan jelas perbedaan statistika pada kelas eksperimen dan kelas kontrol yaitu perolehan nilai rata-rata kelas eksperimen lebih tinggi daripada nilai rata-rata kelas kontrol dengan selisih 7,535. Selain itu, sebaran data dari kedua kelas terlihat bahwa kelas kontrol memiliki sebaran yang lebih heterogen karena memiliki nilai simpangan baku yang lebih besar yaitu 199,08 dan kelas eksperimen sebesar 58,293 . Untuk lebih mempermudah melihat sebaran data dan rata-rata nilai siswa kelas eksperimen dan kelas kontrol dapat dilihat pada Gambar 1 berikut.

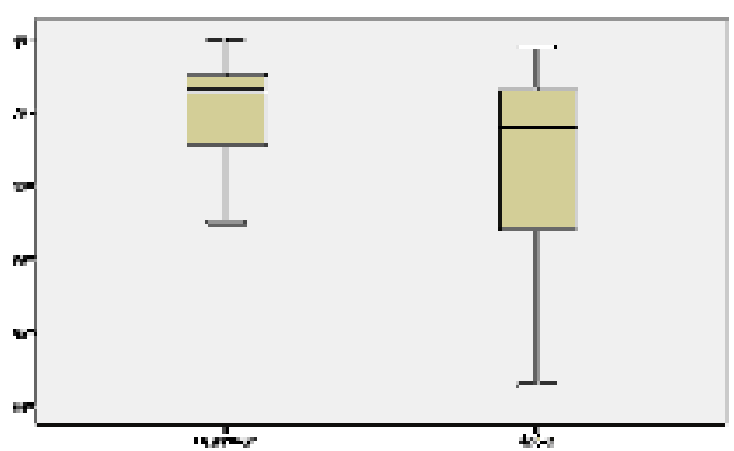

Gambar 1. Boxplot Kelompok Eksperimen dan Kontrol.

Dari Gambar 1, terlihat bahwa garis tengah yang melewati box merupakan ratarata dari data. Jika dibandingkan kedua boxplot menunjukkan bahwa hasil rata-rata nilai post test siswa kelas eksperimen dan kelas kontrol berbeda yaitu nilai rata-rata kelas eksperimen lebih besar daripada kelas kontrol. Jika boxplot semakin semakin lebar, maka data semakin menyebar dan beragam. Gambar 1 menunjukkan bahwa hasil nilai post test siswa kelas kontrol lebih menyebar dan beragam, dibandingkan dengan kelas eksperimen. Dari hal tersebut, menunjukkan bahwa varians dari kelas kontrol lebih besar dari kelas eksperimen. Selain itu, dari gambar di atas menunjukkan bahwa kesimetrisan data dari kedua kelas lebih condong ke kanan yang berarti distribusi kedua kelas sudah mendekati distribusi normal.

\section{Perbedaan}

kemampuan komunikasi matematis siswa kelas eksperimen dan kelas kontrol juga terlihat dari konversi nilai yang didapatkan. Dari konversi nilai tersebut, kemampuan komunikasi matematis siswa kelas eksperimen yang berada pada kategori tinggi sebesar $20,83 \%$ dan tidak ada siswa yang berada pada kategori rendah, sedangkan kemampuan komunikasi matematis kelas kontrol yang berada pada kategori tinggi sebesar $13,04 \%$ dan siswa yang berada pada kategori rendah sebesar $4,35 \%$.

Dengan demikian, secara deskriptif dapat disimpulkan bahwa terdapat perbedaan kemampuan komunikasi matematis siswa yang dibelajarkan dengan model pembelajaran Treffinger dan kemampuan komunikasi matematis siswa 
yang dibelajarkan dengan model konvesional pada kelas X MIA SMA Negeri 1 Sukasada. Hal ini berarti model pembelajaran Treffinger memiliki pengaruh yang positif pada kemampuan komunikasi matematis siswa.

\section{B. Pembahasan}

Kelas X MIA 1 SMAN 1 Sukasada sebagai kelas eksperimen dengan dibelajarkannya model pembelajaran Treffinger dan kelas X MIA 2 SMAN 1 Sukasada sebagai kelas kontrol dengan dibelajarkannya model pembelajaran konvensional. Setelah itu, diberikan post test untuk mengukur kemampuan komunikasi matematis siswa. Post test yaitu hasil belajar matematika siswa setelah diberikan perlakuan pada kedua kelompok untuk mengetahui sejauh mana kemampuan komunikasi matematis siswa. Bentuk post test yang digunakan adalah soal uraian (essay) dengan banyak soal masing-masing kelas 4 nomor untuk post test kemampuan komunikasi matematis siswa.

Berdasarkan hasil post test kepada kedua kelas, diperoleh nilai rata-rata kemampuan komunikasi matematis siswa kelas X MIA 1 setelah dibelajarkan model pembelajaran Treffinger adalah 70,125, sedangkan nilai rata-rata kemampuan komunikasi matematis siswa kelas X MIA 2 yang dibelajarkan dengan model pembelajaran konvensional adalah 62,59. Selain itu, pengaruh model pembelajaran Treffinger dapat dilihat dari perbedaan kemampuan komunikasi matematis kelas eksperimen yang memperoleh nilai tertinggi sebesar 80 dan nilai terendah sebesar 55. Sedangkan kemampuan komunikasi matematis kelas kontrol yang memperoleh nilai tertinggi sebesar 79 dan nilai terendah sebesar 33. Hal ini terlihat dari konversi nilai yang menunjukkan bahwa kelas eksperimen dengan kategori tinggi sebesar $20,83 \%$ dan tidak ada yang berada pada kategori rendah, sedangkan kelas kontrol yang berada pada kategori tinggi sebesar $17,39 \%$ dan yang berada pada kategori rendah sebesar $13,04 \%$.

Dari semua hasil tersebut, maka dapat diketahui bahwa setelah dibelajarkannya model pembelajaran Treffinger, kemampuan komunikasi matematis siswa meningkat 7,535 dari hasil kemampuan komunikasi matematis siswa yang dibelajarkan dengan model pembelajaran konvensional. Dengan demikian, adanya kelas kontrol sebagai pembanding memperkuat bahwa pembelajaran matematika dengan menggunakan model pembelajaran Treffinger lebih efektif. Beberapa hal yang mungkin menyebabkan adanya perbedaan nilai rata-rata antara kelompok eksperimen dengan kelompok kontrol, yaitu pada proses pembelajaran di kelas dan kemampuan komunikasi matematis siswa yang dilihat dari hasil nilai post test siswa yang telah dipaparkan sebelumnya. Berikut akan disajikan penjelasannya terkait proses pembelajaran di kelas.

Tahapan-tahapan pada model pembelajaran Treffinger menjadikan siswa lebih aktif, kreatif, dan pembelajaran lebih bermakna. Siswa dapat mengkontruksikan pengetahuannya sendiri dalam memahami materi dan berani mengungkapkan hasil diskusi saat pembelajaran berlangsung. Selain itu, tahapan-tahapan pada model pembelajaran Treffinger juga dapat meningkatkan pemahaman dan kemampuan menyelesaikan soal matematika dalam kehidupan sehari-hari, sehingga kemampuan komunikasi matematis siswa dapat meningkat.

Hal yang menyebabkan kemampuan komunikasi matematis pada kelas eksperimen lebih tinggi ialah terletak pada proses pembelajaran di kelas. Proses pembelajaran menggunakan model pembelajaran treffinger memiliki beberapa langkah, yaitu 1) Understanding Challange (memahami tantangan) yang terdiri dari tiga tahap yaitu membangun tujuan, menggali data, dan merumuskan masalah; 2) Generating Ideas (membangkitkan gagasan); dan 3) Preparing for Action (mempersiapkan tindakan) yang memiliki dua tahap yaitu mengembangkan solusi dan membangun penerimaan. Selain itu, pada pembelajaran berlangsung akan disajikan LKS yang dapat mendorong siswa lebih bebas menyampaikan ideidenya. 
Sebelum langkah-langkah model pembelajaran Treffinger dilakukan, guru memberikan apersepsi mengenai pentingnya materi yang akan dipelajari dalam matematika dan dalam kehidupan sehari-hari pada awal pertemuan di kelas eksperimen. Hal tersebut membuat siswa tertarik dan termotivasi untuk mempelajari materi yang akan disajikan. Namun, pada awal-awal dibelajarkannya model pembelajaran ini masih belum optimal. Hal itu dikarenakan sisw belum terbiasa dengan penggunaan model pembelajaran Treffinger, sehingga siswa banyak yang bertanya tentang pengerjaan LKS. Banyak siswa kurang berani menuliskan ideidenya, dan bingung dengan langkahlangkah pengerjaan LKS. Selain itu, guru juga masih mendominasi dalam proses pembelajaran sehingga guru sangat berperan penting untuk mengarahkan siswa dalam memahami penyajian materi yang diberikan.

Pada pertemuan berikutnya, siswa sudah dapat menikmati proses belajarnya, mereka terlihat aktif dalam mengerjakan LKS, mereka berusaha menemukan konsep yang mereka pelajari dengan teman sekelompoknya. Hampir setiap siswa dalam kelompoknya memberikan kontribusinya dalam menyampaikan ideidenya, menemukan solusi yang paling tepat dari masing-masing anggota kelompoknya, memberikan tanggapan atas ide-ide yang dikemukakan oleh kelompok lain. Proses pembelajaran yang berlangsung memberikan suasana yang nyaman bagi siswa, sehingga mereka merasa senang dan tidak malu lagi dalam menyampaikan ide-ide mereka.

Siswa diberi masalah yang berkaitan dengan konsep materi yang akan dipelajari. Dari masalah yang ditemukan, siswa akan mencari ide-ide untuk menentukan solusi yang tepat dan sesuai. Solusi yang terpilih akan dipresentasikan di depan kelas, sehingga semua siswa dapat menilai jawaban yang tepat dan sesuai.

Setelah siswa mengungkapkan gagasannya dengan menuliskan hasil diskusi kelompok di depan kelas, siswa akan mempresentasikan ide tersebut. Siswa juga harus mampu mengetahui kelebihan dan kekurangan dari solusi yang diberikan oleh masing-masing siswa. Pada tiap langkah model pebelajaran Treffinger siswa bebas memilih jawaban masing anggota kelompoknya. Siswa bebas menjelaskan ide mereka ke semua anggota kelompoknya dan berusaha meyakinkan kebenaran ide mereka. Dengan demikian, siswa dapat memilih solusi mana yang menurut mereka lebih tepat dan dapat diterima.

Pada proses pembelajaran yang terakhir siswa akan diberikan kuis secara individu. Kuis ini dimaksudkan untuk mengevalusi hasil pembelajaran yang telah dilaksanakan. Berdasarkan deskripsi di atas, langkah-langkah model pembelajaran Treffinger dapat meningkatkan kemampuan siswa dalam memahami konsep sehingga dapat menyelesaikan soal yang lebih sulit. Siswa juga lebih aktif dan kreatif dalam menemukan konsep berdasarkan pengalaman langsung. Siswa dapat bebas saling berargumen dan saling bertukar pikiran antara siswa dengan siswa dan siswa dengan guru. Dengan demikian berdampak pada meningkatnya kemampuan komunikasi matematis siswa.

Dari semua uraian di atas, jelas terlihat bahwa model pembelajaran Treffinger yang dibelajarkan pada proses pembelajaran dalam penelitian di kelas $X$ MIA SMA Negeri 1 Sukasada memberikan dampak positif yaitu siswa mampu menyatakan ide dalam kalimat matematika, menggunakan notasi dengan tepat, menulis gagasan dengan kalimat sendiri, dan melakukan perhitungan dengan tepat. Selain itu, dengan menggunakan model pembelajaran pembelajaran Treffinger siswa lebih percaya diri saat menyelesaikan soal, terlihat lebih bersemangat sehingga mampu meningkatkan kemampuan komunikasi matematis siswa.

Hal ini sejalan dengan penelitian yang telah dilakukan oleh Nizham, dkk (2017) yang menyatakan bahwa pada hasil penelitian di lakukan pada kelas X SHS Jakarta Selatan model pembelajaran Treffinger memiliki pengaruh positif terhadap kemampuan literasi matematika siswa yang salah satunya yaitu kemampuan komunikasi matematis siswa. Dari hal tersebut kemampuan komunikasi 
matematis siswa yang dibelajarkan dengan model Treffinger mengalami peningkatan atau lebih baik daripada siswa yang dibelajarkan dengan pembelajaran konvensional.

\section{SIMPULAN}

Berdasarkan hasil penelitian dan hasil perhitungan statistik deskriptif, dapat disimpulkan bahwa kemampuan komunikasi matematis siswa kelas X MIA SMA Negeri 1 Sukasada yang dibelajarkan menggunakan model pembelajaran Treffinger lebih baik dari pada kemampuan komunikasi matematis siswa yang dibelajarkan menggunakan pembelajaran konvensional. Model pembelajaran Treffinger memberikan pengaruh positif terhadap kemampuan komunikasi matematis siswa.

\section{SARAN}

Adapun saran yang dapat disampaikan berdasarkan hasil penelitian yang telah dilakukan adalah sebagai berikut. Pertama, peneliti lain disarankan agar mengujicobakan pengaruh model pembelajaran Treffinger pada aspek pembelajaran kemampuan komunikasi matematis siswa secara lisan, dan pada aspek pembelajaran yang berbeda, misalnya koneksi matematika, hasil belajar atau prestasi belajar siswa dengan populasi dan materi pelajaran yang lebih luas untuk melihat lebih dalam pengaruh dari model pembelajaran ini. Kedua, praktisi pendidikan, khususnya pihak-pihak yang terlibat dalam pembelajaran matematika disarankan menerapkan model pembelajaran treffinger sebagai salah satu alternatif pembelajaran untuk meningkatkan kemampuan komunikasi matematis siswa.

\section{DAFTAR PUSTAKA}

Ansari, B. I., 2012. Komunikasi Matematik dan Politik, Suatu Perbandingan: Konsep dan Aplikasi. Banda Aceh: PeNA.

Darkasyi, M., dkk. 2014. "Peningkatan Kemampuan Komunikasi Matematis dan Motivasi Siswa dengan

Pembelajaran

Pendekatan Quantum Learning pada Siswa SMP Negeri 5 Lhokseumawe". Jurnal Didaktik Matematika, Vol. 1, No. 1 (hlm. 2134), ISSN: 2355-4185. Tersedia pada

http://jurnal.unsyiah.ac.id/index.p hp/DM/article/download/1336/121 $\underline{7}$ (diakses tanggal 26 Juli 2018).

Hodiyanto. 2017. "Kemampuan Komunikasi Matematis dalam Pembelajaran Matematika". AdMathEdu: Jurnal IImiah Pendidikan Matematika, IImu Matematika dan Matematika Terapan, Vol. 7, No. 1 (hlm. 9-17). Tersedia pada https://media.neliti.com/media/pu blications/177556-ID-kemampuan -komunikasi-matematis-dalampem.pdf (diakses tanggal 5 Pebruari 2018).

Huda, M. 2013. Model-Model Pengajaran dan Pembelajaran. Yogyakarta: Pustaka Pelajar.

NCTM. 2003. "Program for Initial Preparation of Mathematics Specialists". Available at: http://www.ncate.org/ProgramSta ndards/NCTM/NCTMELEMStand ards.pdf (diakses pada tanggal 28 Pebruari 2018).

Nizham, H., dkk. 2017. "Improving ability mathematic literacy, self-efficacy and reducing mathematical anxiety with learning Treffinger model at senior high school students". International Journal of Science and Applied Science: Conference Series, Vol. 2, No.1 (hlm. 130-138), ISSN: 2549-4635. Tersedia pada https://jurnal.uns. ac.id/ijsascs/article/view/16696

(diakses pada tanggal 4 Agustus 2018).

OECD. 2016. PISA 2015 Results (Volume I): Excellence and 
Equity in Education. Paris: OECD Publishing.

Permatasari, N. Y., dkk. (2014). "Meningkatkan Kemampuan Siswa dalam Memecahkan Masalah Matematika dengan Model Pembelajaran Treffinger". Mosharafa: Jurnal Pendidikan Matematika, Vol. 3, No. 1 (hlm. 3142), ISSN: 2086-4280. Tersedia pada http://emosharafa.org/index.php/moshar afa/article/view/mv3n1 4/219 (diakses tanggal 1 Agustus 2018)

Permendikbud, 2016. Lampiran Menteri Pendidikan Dan Kebudayaan No.21 Tahun 2016 Tentang Kompetensi Inti Dan Kompetensi Dasar Pada Kurikulum 2013 Pada Pendidikan Dasar Dan Pendidikan Menengah. Jakarta: Peraturan Kementrian Pendidikan dan Kebudayaan.

Sanjaya, W. 2009. Strategi Pembelajaran Berorientasi Standar Proses Pendidikan. Jakarta: Kencana Prenada Media Group.

Sugiyono. 2012. Metode Penelitian Pendidikan Pendekatan Kuantitatif, Kualitatif, dan R\&D. Bandung: Alfabeta.

Suriasumantri, J. S. 2003. IImu dalam Perspektif. Jakarta: Yayasan Obor Indonesia.
Umar, W. 2012. "Membangun Kemampuan Komunikasi Matematis dalam Pembelajaran Matematika". Infinity Journal Program Studi Matematika STKIP Siliwangi Bandung, Vol 1, No.1 (hlm. 1-9). Tersedia pada http://linkinghub.elsevier.com/retri eve/pii/S0742051X05000387 (diakses tanggal 28 Pebruari 2018).

Undang-Undang Nomor 20 Tahun 2003 tentang Sistem Pendidikan Nasional. Jakarta: Departemen Pendidikan Nasional.

Wahyuni, I., dkk. 2014. "Pengaruh Model Pembelajaran Treffinger Terhadap Kemampuan Berfikir Aljabar Dan Kemandirian Belajar Siswa". Prosiding Seminar Nasional. Pendidikan Matematika Ahmad Dahlan, Yogyakarta 27 Desember 2014, ISSN: 9-772407-749004. Tersedia pada http://www.fkipunswagati.ac.id lejournal/index.php/repository/ article/ view/299/279 (diakses tanggal 26 Juli 2018). 